\title{
ANALYSIS OF THE CAPITULATORY REGIME IN EGYPT IN THE SIXTEENTH CENTURY
}

\author{
Jacopo Crivellaro*
}

\begin{abstract}
This essay analyses the legal regime of Capitulations in Egypt at the apogee of European abuse of the privilege in the Nineteenth Century. Capitulations were trade oriented prerogatives granted to the European merchants by the Sultan of the Ottoman Empire during the Fifteenth and Sixteenth Century. With the weakening of the Ottoman Empire, the privileges were gradually extended to the point that they awarded foreigners substantial immunity from local jurisdiction and legislation. Once Egypt acquired a greater self-governing status with the successful campaigns of Mohammed Ali, the Capitulatory texts were further enlarged by a substantial body of customary law. Custom operated to exempt Western citizens from compliance with local legislation and immunize them from local jurisdiction. The custom acquired an even more aggressive stance when foreign residents were permitted to sue local defendants and request the application of the foreign resident's law. Essentially, Consular tribunals, by administering an inequitable consular justice often in favour of the foreign party,
\end{abstract}


eviscerated the local judicial system of any authority. The practice only subsided with the institution of Mixed Courts of Jurisdiction in 1876 and the Montreaux Convention of 1936.

Keywords: nineteenth century, Egypt, Ottoman empire, capitulations, foreign immunity

\title{
ANALISIS REJIM KAPITULASI DI MESIR PADA ABAD KEENAM BELAS
}

\begin{abstract}
ABSTRAK
Karangan ini menganalisis rejim undang-undang Kapitulasi di Mesir pada kemuncak penyalahgunaan keistimewaan tersebut oleh Eropah pada abad kesembilan belas. Kapitulasi adalah keistimewaan cenderung perdagangan yang dikurniakan kepada pedagang Eropah oleh Sultan Empayar Uthmaniyyah semasa abad kelima belas dan keenam belas. Dengan pelemahan Empayar Uthmaniyyah, keistimewaan tersebut beransur-ansur dilanjutkan ke takat ia menganugerahkan orang asing kekebalan yang cukup besar daripada bidang kuasa dan perundangan tempatan. Apabila Mesir memperolehi status pemerintahan sendiri yang lebih besar dengan kejayaan kempen Mohammed Ali, teks Kapitulasi semakin diluaskan oleh undang-undang adat. Adat bertindak mengecualikan warganegara Barat daripada mematuhi perundangan tempatan dan mengebalkan mereka daripada bidang kuasa tempatan. Adat tersebut menjadi lebih agresif apabila penduduk asing dibenarkan untuk menyaman defendan tempatan dan memohon penerimapakaian undang-undang penduduk asing. Pada asasnya, tribunal konsuler, dengan pentadbiran keadilan konsuler tak ekuiti yang selalunya berpihak kepada
\end{abstract}


pihak orang asing, membuang kuasa daripada sistem kehakiman tempatan. Amalan ini hanya berkurangan dengan pemerbadanan Mahkamah Campur Bidang Kuasa pada tahun 1876 dan Konvensyen Montreaux 1936.

Kata kunci: abad kesembilan belas, Mesir, Empayar Uthmaniyyah, Kapitulasi, kekebalan orang asing.

This essay will draw a brief outline of the capitulatory regime applicable in Egypt at the beginning of the Nineteenth Century. The term capitulation refers to particular international documents arranged in caput or capitulum and affecting the rights of foreign subjects. ${ }^{1}$ Traditionally they were perceived as bestowals of privileges granted by the Muslim leader in full sovereignty of power. ${ }^{2}$ They were understood as unilateral

Latin for heads or articles James Harry Scott, The Law Affecting Foreigners in Egypt (William Green and Sons, Edinburgh 1907) at 68; Jasper Yeates Brinton, The Mixed Courts of Egypt (Yale University Press, New Haven 1968) at 1; Aziz Fahmi, La Conference de Montreaux. L'abolition des Capitulations en Egypte (Librairie du Recueil Sirey, Paris 1938) at 7; Gommaire Louis Dykmans Le statut contemporain des étrangers en Égypte vers une réforme du régime capitulaire (Librairie du Recueil Sirey, Paris 1933) at 12; Aly Delawer, Contribution à l'étude des projets de réforme, concernant la jurisdiction des étrangers en Egypte (Causse, Montpellier 1927) at 17 prefers a variation from the Italian for (accord), (convention).

$2 \quad$ Note Historique Présente Officieusement par le Gouvernement Égyptien lors de la Conférence des Capitulations de Montreux 1937 reported in Léon Roger Christophe, L'Égypte et le régime des capitulations (Les Presses Moderne, Paris 1937) at 1; Erwin Lowenfeld 'The Mixed Courts in Egypt as Part of the System of Capitulations after the Treaty of Montreux' [26] Transactions of the Grotius Society, Problems of Peace and War (1940) at 83; Fahmi at 7; Brinton at 3; Scott at 72; Majid Khadduri and Herbert J. Liebesny Origin and development of Islamic law (AMS Press, New York 1984) at 327; Henri Lamba, De l'évolution de la condition juridique des Européens en Égypte (Rousseau, Paris 1896) at 12 suggesting these concessions were unilateral because of the absence of reciprocity, the style used and the constant renewals. Contrast with J.C. Aristide Gavillot Essai sur les droits des Européens en Turquie et en Égypte (Dentu, Paris 1875) at 7. 
grants rather than as bilateral treaties. By the Nineteenth Century these practices had crystallised into norms of customary law granting fully enforceable legal rights. This essay will address the particularities of the privileges of jurisdiction from a procedural and doctrinal analysis.

\section{GENERAL OVERVIEW OF CAPITULATIONS IN EGYPT}

Capitulatory privileges can be distinguished according to whether they were of a personal or of a commercial nature.

Commercial and trade oriented rights were adapted from the barter economy of the late Middle Ages to suit the necessities of the Nineteenth Century trade market. Certain freedoms provided general principles of commercial practice. These include an expansive freedom of establishment ${ }^{3}$ and the prohibition on discrimination against merchants of a particular nationality. ${ }^{4}$ There was unfettered freedom to import goods and measures to limit the exportation of Egyptian goods could be enacted in so long as the measure applied uniformly to all merchants. ${ }^{5}$

Foreigners were exempted from all taxes other than customs dues. ${ }^{6}$ This was particularly important when the foreign community extended from a merchant based nucleus to a more numerous residentoriented community. ${ }^{7}$ This privilege was inconsistent with traditional practice. Mustamins and other local non-Muslim citizens had not benefitted from similar fiscal rights. ${ }^{8}$ It also led to a paradox regarding ownership

3 Pellissie du Rausas Le régime des capitulations dans l'Empire ottoman (Rousseau, Paris 1910-1911) at 181; Delawer at 23.

$4 \quad$ du Rausas at 198, 206.

$5 \quad$ Ibid at 200.

$6 \quad$ Articles 10,13,18,24,39-42,63,67,73 of the 1740 French Capitulation. Custom dues were imposed on goods imported with a view to sale and on goods that were exported. The values fluctuated from an ad valorem value of 3 to $12 \%$ see Scott at 163 .

$7 \quad$ Georges Meyer, L’Égypte contemporaine et les capitulations (Les Presses universitaires de France, Paris 130) at 191. For a strong critique of the tax exemption suggesting that the Egyptian tax burden was shouldered solely on the fellah and that the consequence of limited customs duties was dependence on foreign capital see Delawer at 65 . Mustamin and resident non-Muslim believers were subject to a variety of taxes including the Land Tax (ushur or Kharadj), the Capitation Poll 
of real property in Egypt. This was because foreigners in Egypt had had the opportunity to own real estate before the 1867 Firman $^{9}$ yet were always exempted from the heavy burden of property tax. ${ }^{10}$

Personal capitulatory privileges included the right of foreigners to practice their own religion, which was interpreted in a particularly expansive manner to include the right to construct churches and wear religious garments. ${ }^{11}$ Foreigners were also permitted to inherit property according to their own national laws of succession. ${ }^{12}$

Foreigners enjoyed an expansive right to inviolability of domicile, whereby local authorities could enter a foreigner's domicile only in case of necessity and with the consent and presence of consular authorities. ${ }^{13}$ Domicile was interpreted widely and even included a foreigner's place of business. ${ }^{14}$

Tax (Jjzyah) and the Takalif Urfiah, Awani (extra-legal imports, and other vexatious exactions) See generally Meyer at 111,192-195; Scott at 171.

The June $10^{\text {th }} 1867$ Firman accorded foreigners the right to own property, yet this benefit was strictly regulated under Ottoman law without any consular involvement in the administration, interpretation or execution of the law.

$10 \quad$ Meyer at 184, 202; Lamba at 72, Gommaire Louis Dykmans Le statut contemporain des étrangers en Égypte vers une réforme du régime capitulaire (Librairie du Recueil Sirey, Paris 1933) at 57. This privilege was revoked by the reforms of 1880 which greatly simplified the tax regime and abolished the Jizyah. However, the imposition of taxes on foreigners could still only be levied with the foreign government's consent. See Mixed Court of Alexandria, Judgment of 13 March 1884 reported in Scott at 173-175.

$11 \quad$ Article 6, 1535 Capitulation; Meyer at 171; Scott at 161; Delawer at 23; see also du Rausas at 187 suggesting the usage expanded beyond religious schools to a complete freedom for all educational establishments.

12 Scott at 174, reports how it was a privilege recognised since the Keit Bey capitulation of 1488.

$13 \quad$ Scott at 156. See also Lamba at 42.

$14 \quad$ Scott at 156; du Rausas at 181; Meyer at 177, 182. Domicile was defined to include the home, courtyards, gardens, curtailed and enclosed contiguous spaces as well as places of business. 


\section{IMMUNITY FROM NATIONAL JURISDICTION AND LEGISLATION}

The following section seeks to focus on the two pivotal aspects of the Capitulatory regime, namely the immunity from national jurisdiction and legislation. It was the immunity from national jurisdiction and national legislation more than other privileges which marked the abusive situation of foreigners in Egypt in the Nineteenth Century. In fact, if an alien resident is immune from local courts and subject to a foreign tribunal which applies foreign laws it becomes a legal fiction to consider him living in any country other than that foreign state (which oftentimes was his state of origin).

To clarify, the formal law of capitulations applicable (that expressed in formal capitulatory agreements and the law that was applicable in Istanbul) was that which had been enacted in the 1740 Capitulation or later capitulations. In the Nineteenth Century it provided that:

1) For litigation between foreigners of the same nationality, jurisdiction was vested in the consul of the parties. Local courts would not have standing to interfere, unless the parties consented. ${ }^{15}$

2) For litigation between foreigners of different nationalities, the dispute could be settled by local justice if both parties consented or would have otherwise been adjudicated by remittance to the respective ambassadors. ${ }^{16}$

In an attempt to encourage parties to access local justice rather than remit the case to their respective ambassadors a system of Mixed Courts was introduced in Istanbul in 1820. It provided significant procedural advantages over traditional Muslim Courts, ${ }^{17}$ especially as it applied legislative codes which were heavily inspired by French legislation. ${ }^{18}$

\footnotetext{
$15 \quad$ Article 52, 1740 French Capitulation.

$16 \quad$ Article 52, 1740 French Capitulation; Lamba at 68; Scott at 190.

17 Scott at 85, suggests advantages included the use of written evidence and permission for Christians to serve witness against Muslims.

$18 \quad$ Scott at 89.
} 
These courts were composed of two judges from the defendant's nation and a judge from the plaintiff's nation.

These courts operated until 1864 when a decision of the Court of Appeal of Aix questioned their jurisdiction in light of Article 52 of the 1740 French Capitulation. By decreeing that jurisdiction of the Mixed Courts was purely voluntary, Mixed Courts lost all authority and were rapidly abandoned. ${ }^{19}$

3) For litigation between a foreigner and a national citizen, jurisdiction was vested in the tribunal of the Imperial Diwan with appeal directly to the Sultan. ${ }^{20}$

The tribunal of the Imperial Diwan ${ }^{21}$ was a specialized tribunal, as the President was specifically appointed because of his familiarity with foreign customs. ${ }^{22}$ The foreign litigant's position was safeguarded by additional procedural regulations, including a requirement that all incriminating evidence be authenticated documentary evidence, ${ }^{23}$ and the compulsory presence of the consular dragoman. ${ }^{24}$ However in these tribunals disputes on the interpretation and application of the law were rare as the judge was primarily called to resolve factual issues. ${ }^{25}$

4) For criminal litigation with a foreign defendant, authority was vested in a Mixed Committee consisting of Ottoman officials and the diplomatic officials of the defendant's nation. ${ }^{26}$

$19 \quad$ Judgment of 22 November 1864, Affaire Pigeon et consorts contre l'Autrichien Issaverdens. Brinton at 6; see also for a critique of the unnecessarily stringent literal interpretation of Article 52 in Meyer at 93-94.

20 Article 26, 1740 French Capitulation; Scott at 183-186.

21 Alternatively referred to as the Tribunal of the President of the Customs House.

22 Scott at 185; Lamba at 73.

23 Article 4, 1535 Capitulation.

24 Article 16, 1580 Capitulation; Brinton at 4; Lamba at 70 suggests the purpose of the dragoman's presence was primarily to help in the communications between the foreign party and the local authorities.

$25 \quad$ Scott at 187.

$26 \quad$ Article 42, 1740 Capitulation. 
The Mixed Committee was organized as a council of arbitration, exercising more of a diplomatic rather than judicial role. As such, compensatory damages rather than criminal sentences were generally imposed. ${ }^{27}$ In the limited instances when punishment was decreed, the execution of the judgement would be left to the Consular authority. ${ }^{28}$

However, this "formal law" was supplemented in Egypt by a corpus of customary law ${ }^{29}$ whose existence was perceived as indispensable and validity as irrefutable. ${ }^{30}$ While custom usually sets general principles or specifies the interpretation of treaty documents, in this case the customary capitulatory principles overruled the capitulatory provisions in their entirety. The custom that emerged was wholly onesided as it always favoured the foreign litigant by subtracting from the local justice virtually all disputes where he was a party.

The primary modifications of custom were:

1) For civil and criminal litigation between foreigners of different nationalities, Article 52 of the 1740 French Capitulation was entirely overruled by the actor sequitur forum principle. ${ }^{31}$ The article provided that mixed-foreigner disputes would be heard by the local justice if both parties consented or the case would be resolved by ambassadorial recourse. In practice, mixed foreign disputes were always heard by the consular tribunal of the defendant party.

Article 42, 1675 English Capitulation.

Article 5, 1718 Austrian Capitulation; Scott at 188.

du Rausas at 246 ; For a definition of custom see Meyer at 157-160;

[the customary regime comprised] "toute une jurisprudence internationale qui a développe ces traites, toute une série de dispositions complémentaires conçues dans le même esprit, conseillées par l'expérience, reconnues nécessaires, admises d'un commun accord, consacrées par l'usage et garanties enfin par les plus récentes conventions."

See also the interesting study of the Italian judge of the Mixed Tribunal in Alexandria, M. Messina for an analysis of the sources of customary capitulatory law, and the time frame whereby what was a recommendation becomes a legally enforceable provision in Meyer at 160.

Lamba at 68; Meyer at 157.

Scott at 198-192; Lamba at 68. 
Mixed Courts were reluctantly accepted by foreigners and were definitively abandoned with the 1864 decision of the French Court of Appeals. Resort to the respective ambassadors in Istanbul was also rejected because it would have required the parties to travel to the capital. ${ }^{32}$ As a consequence, parties applied to the local consuls as representatives of the ambassadors. In choosing between the two different consuls, that of the defendant and that of the plaintiff, the former was favoured because the defendant's consul offered certainty of competence (the defendant's consul could not refuse jurisdiction) and certainty of execution (the defendant consul was the sole authority empowered to execute the sentence). ${ }^{33}$

Objectively, subtracting these mixed foreign disputes from local justice would hardly offend Egyptian sovereignty, for the overall bearing of these cases on Egypt was likely to be minimal. Egypt might have been the locus of the disputes, but the interests at stake would probably have been of foreign ownership.

2) For civil ligation between a foreigner and a national citizen jurisdiction was vested in the tribunal of the Imperial Diwan under Article 26 of the 1740 Capitulation. As the Imperial Diwan was located in Turkey, access for Egyptian parties was limited. Therefore Egyptian Mixed Courts were introduced in 1839. The instauration of these courts did not affect the substance of the capitulatory arrangements, for it was a change in terminology rather than substance.

The Mixed Courts established in 1839 were composed of an equal number of Egyptian and foreign arbiters chosen by lot from the merchant communities of Alexandria and Cairo. ${ }^{34}$ Several rules of procedure safeguarded the foreign litigant with additional protections.

$32 \quad$ Dykmans at 54; Lamba at 68.

$33 \quad$ Scott at 191; Meyer at 68; Dykmans at 54; Lamba at 68. Certainty of execution was relevant because for example, the defendant's consul could refuse to enforce the judgment of a different consular tribunal (i.e. that of the plaintiff).

34 Byron Cannon Politics of Law and the Courts in Nineteenth Century Egypt (University of Utah Press, Salt Lake City 1988) at 25; Dykmans at 
In practice these procedural requirements were abused by foreign powers, as in all cases where consular cooperation was required, the consul had an easy opportunity to eviscerate the whole process of any efficiency. For example, a procedural obligation required the consul to grant leave to the consular dragoman to attend the litigation ${ }^{35}$ and entrusted in the consul the sole authority to enforce the judgment. ${ }^{36} \mathrm{As}$ a consequence the consul could easily delay or prevent the administration of justice by refusing to grant leave for the dragoman to attend. ${ }^{37}$ As the dragoman was himself immune from local jurisdiction and accountable only to the consul, local administration lacked any authority to ensure the dragoman's presence.

In many instances the consul would also refuse to grant leave for the dragoman to attend without having evaluated the merits of the case. This was the equivalent of creating a preliminary assessment of the merits, thus lengthening the litigation.

The consul would also often refuse to enforce the judgment without having accurately heard the evidence against his national, thereby creating a further stage of litigation after a native litigant had succeeded in the local courts. ${ }^{38}$

These inconveniences created a multilayered administration of justice, with certain stages where resort to the consulate or the consular tribunal became necessary. It is understandable why whenever the disputes were urgent even local litigants would have preferred a single trial at the consular tribunal rather than a protracted litigation in several venues. ${ }^{39}$

The practice of having disputes with local plaintiffs and a foreign defendant adjudicated by consular courts rapidly crystallised into a customary norm. This solution could be justified under a strict application of the actor sequitur forum principle. If the objective was to permit

58; see also Brinton at 7 describing the impracticalities of the election process, if arbiters had to be chosen from the many different ethnic and religious communities present in Egypt.

$35 \quad$ Lamba at 71.

$36 \quad$ Lamba at 71; Scott at 197.

37 J.C. Aristide Gavillot Essai sur les droits des Européens en Turquie et en Égypte (Dentu, Paris 1875) at 52.

38 du Rausas at 243.

$39 \quad$ Fahmi at 20; Meyer at 97, 183. 
defendants access to the court of their choice, then permitting a defendant alien's resort to his own tribunal is understandable. However, the customary norm also permitted a foreign plaintiff to sue a native defendant in the consular tribunal. It is in this instance that the customary norm becomes discriminatory and not legally justified. In fact, the result was paradoxical. A privilege of jurisdiction which had originally been granted to avoid foreign parties from the unfairness of being tried in local courts, was now applied so as to disfavour national citizens which would themselves be tried by alien courts.

3) For criminal litigation between foreigners and local litigants, the capitulations would have vested authority in the Mixed Committees composed of joint local and foreign representatives. Customary practice divested this mixed tribunal and made criminal disputes a field of exclusive consular jurisdiction.

Certain scholars suggest that substituting consular tribunals for local courts in cases of criminal jurisdiction was the consequence of the inviolability of a foreigner's domicile coupled with the exclusive authority of consuls to enforce judgments. ${ }^{40}$

Consular authorities also enjoyed considerable discretion over police forces in Egypt. A foreigner caught in flagrante delicto could be arrested by local authorities although notice of the arrest had to be immediately reported to the Consular authority and the case would then be tried by consul. Where the foreigner had been arrested without the consul's consent, the consul could order immediate liberation and commence proceedings against the police officers for wrongful arrest. ${ }^{41}$ Unsurprisingly, this meant foreigners were only arrested at the consul's request. As a consequence of the difficulty for local justice to apprehend a foreign criminal, and the lenience of certain consulates to try their own nationals Egypt became, according to a scholar, the land where "assassins roamed free." ${ }^{2}$ The Egyptian government would also have had no

\footnotetext{
$40 \quad$ Dykmans at 58; Lamba at 75.

$41 \quad$ Scott at 200; Lamba at 43.

42 Fahmi at 23. See also, 1681 Ordinance to French Consuls, and Article 82, 1778 French Edict granting the French Consul authority to expel his
} 
possibility to pursue claims where the native claimant had accepted indemnification or refused to continue the litigation in the consular court. ${ }^{43}$

The consequence of vesting consular tribunals with criminal jurisdiction and allowing consuls a large scope of autonomy to prosecute crimes and torts meant that the very sovereignty of the nation was undermined. The internal administration lacked the judicial authority to legislate and enforce the regular laws of the land upon foreigners.

In conclusion, custom affected the general capitulatory framework of adjudication by providing that:

1) All litigation between foreigners of the same nationality was tried by the foreigner's consul.

2) All litigation between foreigners of different nationalities followed the actor sequitur forum principle and was tried by the defendant's consul.

3) Civil or commercial law suits brought by a national citizen against a foreigner, were adjudicated only by the foreigner's consul.

4) Civil or commercial law suits brought by a foreigner against a national citizen, were adjudicated only by the foreigner's consul.

5) All criminal jurisdiction for cases involving foreigners was assessed under the actor sequitur forum principle, and in all cases excluding local jurisdiction.

own nationals who for "Mauvaise conduit et par ses intrigues pourrait être nuisible au bien générale.” He was also granted authority to prosecute crimes (prévu par les traites ou autorisés par les usages). This clarifies how consular authorities retained a general policing power of foreign nationals, so that "assassins roamed free" should really read "assassins roamed free from local justice, but were still accountable to their own foreign consulate,” in Lamba at 50; Meyer at 84.

$43 \quad$ Lamba at 77-78; Dykmans 58. 


\section{CAPITULATIONS IN EGYPT IN THE NINETEENTH CENTURY}

The capitulatory regime in Egypt in the Nineteenth Century was clothed in legality. It enacted abusive and discriminatory practices disfavouring the local litigant vis-a-vis the foreigner but always with reference to general principles and practices of law. In this final analysis of the regime, I will address certain salient aspects of the exercise of consular jurisdiction which remain relevant in the modern world despite the demise of capitulations in Egypt.

The following section seeks to briefly delineate the consular tribunals' subject matter jurisdiction, and certain relevant procedural aspects including the right to appeal and the application of the actor sequitur forum principle.

\section{i. Jurisdiction of the Courts}

Consular courts enjoyed almost universal subject matter jurisdiction over disputes where one party was a foreigner. This included sectors which are generally reserved to national courts because of the strong national interests involved. For example, granting consular courts the ability to hear disputes over real estate adversely affected the rise of credit financing or mortgage systems in Egypt. The ability to trade in real property was also hindered by the disparate and conflicting standards of the many separate consular tribunals. ${ }^{44}$

A consequence of the extensive subject matter jurisdiction of consular courts was that foreigners enjoyed an almost complete immunity from the application of Egyptian law. ${ }^{45}$ As a foreigner would never have

\footnotetext{
$44 \quad$ Dykmans at 57; de Raussas at 253, 271; Lamba at 79.

45 du Rausas at 253, 255; Scott at 198-199; cautions from considering immunity from application of Egyptian law as equivalent to immunity from the law in general. Compare with Marta Petriccioli Oltre il mito, L'Egitto degli Italiani (Mondadori, Milan 2007) at 2-3; giving abundant examples of Italian members of the community expelled by the Consul Della Croce after a complaint had been filed by British diplomats. On the other hand, the assassins case of Solomon Cicurel, Eduardo Monamarco and Grimaldi Danaro in 1927 saw the Italian accomplices
} 
been subject to a local court, he would only face the obligations of local law where the law of his state of origin provided for local law to apply under the locus regit actum principle. ${ }^{46}$

Most consular tribunals only permitted extra-territorial appeals. The appealing court would lie at Istanbul for the British consular tribunal, Aix was the venue for French appeals, Ancona for the Italian Kingdom and Athens for the Greek Kingdom. ${ }^{47}$ The inconvenience for a local litigant to seek appeal made consular decisions virtually beyond review. ${ }^{48}$

What is more, even between two foreign litigants this procedural posture operated anomalously. In the case where two foreign plaintiffs had been tried by the consular tribunal of one of the two parties they would still enjoy the right to appeal the judgment at their own national appellate court. As there was no hierarchy of appellate tribunals, if the appellate tribunals decreed different judgments there was no way to decide which of the two appellate judgments to enforce. ${ }^{49}$

The principle of actor sequitur forum was the main development of custom over the traditional capitulatory jurisdictional scheme, encroaching in a field which the Ottoman Empire had purposefully excluded from the scope of capitulatory concessions. ${ }^{50}$

subtracted from Egyptian justice and avoiding the death penalty that would have been sentenced had they faced a trial in local courts (and which their Egyptian accomplice incurred). See Brinton at 5, Auckland Colvin The Making of Modern Egypt (Selley \& Co, London 1906) at 203. See also the description by Meyer at 153 quoting du Rausas (Il résulte de la que les lois Egyptiennes sont, par rapport aux étrangers, comme si elles n'existaient pas, et que l'Etat égyptien, dans l'exercice de son action administrative vis-à-vis des étrangers, ne peut pas prétendre qu’il exécute ou appliqué une loi). Lamba at 36.

Lamba at 34; Hoyle at 6; Dykmans at 55; Gabriel M. Wilner, 'The Mixed Courts of Egypt: A Study of the Use of Natural Law and Equity' University of Georgia School of Law, available at http:// digitalcommons.law.uga.edu/fac artchop/210 at 409.

Mark S.W. Hoyle Mixed courts of Egypt (Graham \& Trotman, London 1991) at 7.

Fahmi at 22; Dykmans at 55, with reference to two litigants appealing the same judgment one in Odessa and one in London, and the enigma of which appellate judgment be granted priority.

du Rausas at 248, suggests that actor sequitur was initially a procedural rule, which then became a substantive right. 
The frequency with which the maxim was invoked by foreign litigants would presuppose its efficiency as a principle of law. However, commentators have highlighted many flaws in its application in both mixed jurisdiction as well as litigation amongst foreigners.

Procedurally actor sequitur forum entailed a high degree of administrative inefficiency. Joinder of multiple defendants of different nationalities was not permitted, ${ }^{51}$ and where a party served a counterclaim it was litigated at the tribunal of the party on whom the counterclaim was being served rather than at the tribunal which had already been vested with jurisdiction for the original action. ${ }^{52}$ Furthermore, if new property or evidence became available it could only be adjudicated by the consulate seized of the property by an extension of the principle. ${ }^{53}$ In practice, it meant that contractual parties were often uncertain in the case of a dispute as to which law applied, as it depended on which party was the defendant. This was, understandably, the form of unpredictability which discourages reliance and respect for the law. ${ }^{54}$

\section{ii. Justifications for the Extension of Customary Capitulatory Law in Egypt}

Having outlined the general framework of the customary regime applicable in Egypt including the scope and extent of consular jurisdiction, the following section addresses some of the reasons given by contemporaneous scholars to justify this deviation from the traditional capitulatory agreements.

Many scholars concur that national courts in Egypt were perceived as unsuitable for foreign disputes because they administered a law which was seen as outdated when compared to the foreign codes of law. ${ }^{55}$ When French codes were later largely re-enacted in Egyptian

\footnotetext{
$51 \quad$ du Rausas at 271; Meyer at 96; Lamba at 80.

$52 \quad$ Scott at 204; Lamba at 79; du Rausas at 270; Dykmans at 55.

$53 \quad$ Dykmans at 56.

$54 \quad$ Hoyle at 7; Lamba at 79; Dykmans at 55; Brinton at 6; All authors agree on the absurd commercial result whereby parties strove to provoke suit before their own consul.

$55 \quad$ Article 56, 1740 French Capitulation; Dykmans at 56; Cannon at 41; Hoyle at 8; du Rausas at 248-250.
} 
legislation, the worsening financial conditions desisted foreign litigants from entrusting adjudication of matters to the local administration. Professor Cannon suggests the Egyptian "impecuniosities" and the foreigner's fear for economic debacle provided the stimulus to vest all disputes in a familiar system of law. ${ }^{56}$

If one concludes that local courts were excluded because of their inefficiency, Ottoman courts in Istanbul because of the inconvenience of travelling overseas to have cases heard, then the only viable alternative would be local consular jurisdiction. ${ }^{57} \mathrm{~A}$ cynical view would suggest that this was the original objective of foreign powers; to take advantage of the Egyptian Khedive's "want in vigilance" and "heedlessness in failing to resist" and substitute a foreign system of justice. ${ }^{58}$ Jurist Georges Meyer provides a more neutral assessment, suggesting that the codified capitulatory texts were never meant to have a uniform application throughout the Ottoman Empire, but were general standards which the local social and economic differences of each constituent part could affect. ${ }^{59}$

\section{iii. Analysis of Capitulatory Privileges}

Having addressed the extent of the customary capitulatory privileges, and analysed the possible justifications for this development, this final section seeks to evaluate the system in light of objective goals of efficiency and equity.

With minor exceptions, it is uncontested that capitulations were abusive intrusions in Egyptian national sovereignty. ${ }^{60}$ Yet criticism distinguishes between the doctrinal elements, such as the deficiencies of customary law, and the factual elements, such as the fairness with which consular tribunals operated.

\footnotetext{
$56 \quad$ Cannon at 44.

$57 \quad$ Lamba at 71-72; Scott at 192.

$58 \quad$ Baring Cromer at 427; Scott at 196; Meyer at 84.

$59 \quad$ Meyer at 139-141, 162.

60 Only Gavillot at 322-401, attempts to support the view that capitulations did not affect Egyptian national sovereignty.
} 


\section{iv. Criticism of the Customary Capitulatory Regime in Doctrine $^{61}$}

Many scholars concur that the insistence with which foreigners claimed particular privileges was an inequitable reliance on capitulatory texts. ${ }^{62}$ It was inequitable as these were concessions granted in different contexts which the changing social conditions should have rendered obsolete. It was also inequitable that privileges which originally had a minor impact on national sovereignty (when the foreign community was minimal ${ }^{63}$ became significant encroachments when the community expanded and the jurisprudential conception of the law shifted towards territoriality. ${ }^{64}$

$61 \quad$ See also Meyer at 165, 171 who suggests Western academia err in focusing solely on custom as the source of abuse, when capitulatory texts always recognised the presence of custom as a binding source of law (Article 2, 1535 Capitulation; Article 15, 1740 French Capitulation). He therefore concludes that an analysis of the legitimacy of capitulations should assess both the textual and the customary aspect.

He also challenges the view that custom can be abusive per se for custom only evolves gradually with the acquiescence of both parties. He challenges the conception of customary law as a unitary body, for he asserts that local and national custom existed, as well as custom derived from Europe and custom which originated from universal merchant practices.

See also Lamba at 6, who suggests that the corpus of customary law rather than re-defining the law, simply applied exemptions in the field of jurisdiction, taxes and property law in so incoherent a manner to form "anarchie judiciarie.”

62 Christophe at 12, Dykmans at 7-8, quoting Lord Milner's statement that Egypt had become the "land of paradox" amongst other reasons because it permitted outdated practices which no longer bore their original purpose, and whose endurance despite changing conditions mystified Western scholars.

63 See Lamba at 30, suggesting that in 1613 there were at most 50 French and Venetian merchants in Constantinople. These numbers would be greatly increased with the influx of European emigration to the Levant during the Nineteenth Century.

$64 \quad$ Christophe at 35; Meyer at 42; Lamba at 30 suggesting capitulations at first served a commercial justice, with almost all disputes between a limited number of merchants on short business trips and unable to purchase real property. This exercise of sovereignty did not hinder the Sultan's sovereignty. 
Therefore, while permitting foreign merchants in the Fifteenth Century to adjudicate their own trade quarrels independently was justifiable, permitting foreigners to determine questions of residence and permanent habitation in the Nineteenth Century was inequitable, ${ }^{65}$ even if the same provision was invoked to justify the exercise of the right.

Scholars have been more cautious in determining whether the customary corpus of law violated international law. ${ }^{66}$ Clearly, the 1740 French Capitulation was a lawful international agreement, ${ }^{67}$ and many influential scholars regard the customary extensions justified by the tacit acquiescence of the Egyptian government. Others suggest that the customary modifications, which might have had a doubtful legal validity at first, came to acquire legally binding force as customary principles. ${ }^{68}$ This would find legality in ex posto facto recognition of their widespread application rather than on a notion of consent. A final strand of scholarly writings purports that customary principles were a lex specialis which overruled the codified text of the capitulations, ${ }^{69}$ or else, the creation of the customary rule marked the desuetude of the former capitulatory provision. ${ }^{70}$

A recurring theme in academic writing suggests that customary capitulations only define what was essentially an extra-territorial exercise of jurisdiction. ${ }^{71}$ This approach is inherently flawed. It could have been

\footnotetext{
$65 \quad$ Cannon at 41.

66 While assessing lawfulness of capitulations, the intertemporal rule should be considered, so that the standard should be the law at the time of capitulations.

$67 \quad$ Meyer at 266.

68 du Rausas at 264; suggests that custom is legal so long as it is certain and undisputed. The clarity of this reasoning is undermined by its inherent tautology. In fact, custom is only undisputed and certain when it is legal.

69 If custom operated as a lex specialis, then the academic investigation should focus on the exact point in time in which customary rules crystallised to overrule black letter capitulatory provisions. See generally du Rausas at 12; Meyer at 111.

70 Recognised as possible in the Judgment of the Aix Court of Appeal of 04 March 1896, suggesting that French protection over unrepresented foreigners had lapsed into desuetude as a capitulatory provision, and could not be exercised against the defendant's wishes; du Rausas at 19.

$71 \quad$ Fahmi at 8.
} 
applicable at the embryonic stages of European presence in the Levant, for example during the Sixteenth Century when foreign merchants were all secluded within the funduq and under the authority of their respective consul. ${ }^{72}$ Yet, in the Nineteenth Century there would be no physical territory upon which the extra-territorial jurisdiction could objectively apply. ${ }^{73}$ Considering the consulate an extra-territorial appendage of the state would not allow the notion of extra-territorial jurisdiction for all matters which would have arisen outside the premises of the consulate. These would have been almost the entirety of the cases heard by the consul tribunals. ${ }^{74}$

In conclusion, the justifications advanced to legitimise the customary body of law seem tenuous. Egypt repeatedly attempted to curb foreign privileges but was politically coerced into accepting the status quo. ${ }^{75}$ Thus any conception based on Egypt consenting or acquiescing is unrealistic. Assessing the customary practices under a purposive rather than a legal understanding reveals the same unconvincing result. Jurisprudentially, the capitulations furthered territoriality of the law, but this was not an objective either Egypt or the Ottoman Empire was pursuing, but quite the contrary. ${ }^{76}$

In conclusion, even assuming the legality of the customary modifications, its operation as a body of law was clearly inequitable. ${ }^{77} \mathrm{It}$

72 Lamba at 19, 57, 59-60 (reporting views of Vercameer, Feraud Giraud and Roccasserra); Dykmans at 33; Philip Marshall Brown 'The Capitulations' [1] Foreign Affairs (1923) 4 at 72.

73 Lamba at 6.

74 Alternatively all foreign domiciles could be considered foreign territory, (as asserted by Lamba at 57). Yet this would lead to absurd results, for example if a foreigner sheltered himself in another foreigner's house a mandate for extradition would be necessary. Furthermore it would still not justify consular jurisdiction for all matters where the factual dispute was committed by a foreigner outside of his home.

75 For example the attempts to introduce the Said Pascha Regulations 1857, or to enforce the 1867 Boureé Protocol.

76 du Rausas at 270, warns from an excessive focus upon personality of the law, for in most cases one of the party's right to be tried in aspects of his own personal statute by his own court would always be violated.

77 Dykmans at 57; Hoyle at 3, 7. Compare with Meyer at 113, who suggests that some of the limitations of sovereignty were a necessary evil to attract foreign investment. 
left Egypt powerless to tax a wealthy portion of its residents, without authority to enforce criminal laws against a whole section of society, with no jurisdiction over commercial affairs of an international dimension and without the possibility of ensuring a just solution for its own citizens' disputes with foreigners. ${ }^{78}$

\section{v. Criticism of the Capitulatory System in Practice}

Regardless of the legitimacy of capitulatory custom, most criticism for the regime of capitulations arises from the abusive exercise of these rights by consular tribunals. ${ }^{79}$ While many scholars recognise that the consular tribunals of the major powers offered a scrupulous and just administration the practice was not uniform. ${ }^{80}$

The exercise of jurisdiction was especially abusive in bankruptcy cases, where claimants sought consular jurisdiction to avoid the consequences of insolvency and taxation, even if they had lived in the local country taking full advantage of its institutions their whole lives. ${ }^{81}$

Possibly, practice only exemplified the fallacies of a system which was inevitably prone to abuse because of its particular framework. The difficulty of seeking appellate review meant that consular tribunals had almost unfettered freedom to adjudicate. The choice of the consul as the administrator of justice rather than an independent (even if foreign) judicial officer also meant that the exercise of jurisdiction was inevitably tied with political considerations. ${ }^{82}$ The rigid application of actor sequitur

\footnotetext{
$78 \quad$ Hoyle at 3,7.

79 Especially for abuses which offended the local customs and decorum, such as the improper monitoring of foreigner's activities in gambling houses, dance halls and other pleasure resorts. See generally Marshall Brown at 73, 74.

Dykmans at 57; de Raussas at 251; Both authors highlight statistics which evinced how from January 1866-July 1867 the French Consular tribunal heard 70 cases of which 61 were decided in favour of the native party.

81 Meyer at 69-70; Yahya Hasan Abd Kâdir Les passeports et la résidence des étrangers en Égypte (Journal du Commerce et de la Marine, 1953) at 5 .

82 Cannon at 44, asserts how the consul was often petitioned to commence action against the local government to recover unfruitful investments.
} 
forum also meant that consulates could easily collude to hinder a local litigant's claim by transferring goods and properties between themselves, thereby forcing the applicant to begin a new law suit at each different consular court. ${ }^{83}$

However, all these considerations have ignored the legitimacy of consular tribunals as a judicial organ per se. In fact, consular tribunals were inherently undemocratic. An unelected (in both Egypt and the country of origin) unrepresentative and unaccountable foreign consul had the authority to bind the local population while applying foreign law. ${ }^{84}$ The consul exercised his authority in clear violation of the principle of separation of powers as he was entrusted with legislative duties, enforced the judgment as the executive officer and adjudicated the dispute. ${ }^{85}$

\section{CONCLUSION}

The regime of capitulations was an important element of the interactions between the Eastern and the Western world from the early Middle Ages until the beginning of the Twentieth Century. An analysis of the regime evinces many of the prejudices that have plagued the Western world in their misunderstanding of Islamic law and culture. In this sense, the demise of the regime was a step forward in permitting the development of equalitarian relations between Western and Muslim states.

Yet, has this goal been achieved? Have western citizens and nations really dealt with Muslim states on an equal footing?

The political rather than legal pressure the consul could exert would often compel local governments to pay outs which it had no authority to review.

$83 \quad$ Scott at 204; Hoyle at 7; Meyer at 96.

$84 \quad$ Meyer at 149.

$85 \quad$ Scott at 192; du Rausas at 251. 